\title{
Cells Involved in the Mitogen-Induced Helper Function which Facilitates the Blastogenic Response to Actinomyces viscosus
}

\author{
Dennis E. Lopatin, Dennis F. Mangan, and Irene S. Horner \\ Dental Research Institute and Department of Oral Biology, School of Denistry, and Department \\ of Microbiology-Immunology, School of Medicine, University of Michigan, \\ Ann Arbor, Michigan 48109
}

Received September 16, 1980

\begin{abstract}
Coculture of human peripheral blood lymphocyte suspensions, previously pulsed with either pokeweed mitogen (PWM) or an Actinomyces viscosus ultrasonicate supernatant fraction ( $\mathrm{AV}$ ), resulted in a blastogenic response that was greater than the sum of the responses of the two independently cultured lymphocyte suspensions. Selective cobalt-51 irradiation of the precultured lymphocytes prior to coculture revealed that PWM was inducing a helper activity which facilitated the blastogenic response to the poorly mitogenic AV. Subsequent experiments revealed that both B- and T-enriched lymphocyte populations were capable of providing such help, however, the B-cell help appeared to require T-cell interaction. As few as one PWM-activated helper cell per 150 AV-pulsed cells was sufficient to provide measureable help. In the presence of PWM helper cells, both $\mathrm{B}$ and $\mathrm{T}$ cells gave strong blastogenic responses to $\mathrm{AV}$ fractions. Results of this study suggest that lymphocytes can respond to poorly mitogenic substances from bacteria if helper cell activity is provided by a second, unrelated lymphocyte stimulant.
\end{abstract}

\section{INTRODUCTION}

Inflammatory lesions in the periodontium of man (1-4) and rodents (5) have been associated with the presence of certain species of Actinomyces. The prevalence of these organisms in mature dental plaque and their ability to activate macrophage and neutrophil degranulation (6), and stimulate lymphocytes from patients with periodontal disease (7-9) has implicated them in the etiology of gingivitis and periodontitis. It has been hypothesized that various host immunological responses to these organisms are responsible for initiating periodontal inflammation (7). Several laboratories $(10,11)$ have demonstrated B-cell mitogenic activities in extracts of Actinomyces viscosus (AV) using murine models. However, the mitogenicity of these substances for human lymphocytes from individuals free of gingival disease has, until recently, been discounted (12). In our previous report (13), we showed that AV pulsing of human lymphocytes from healthy individuals with such extracts, followed by stimulation with pokeweed mitogen (PWM), resulted in an amplified blastogenic response when compared to the sum of the responses to either AV or PWM. These studies showed that under those conditions, there was no mitogenic response to $A V$ when cultured alone with human lymphocytes. However, it was not clear from our preliminary studies whether the amplified response resulted from AV amplifying the lymphocyte response to PWM, or by a PWM-stimulated helping activity permitting the lympho- 
cytes to respond blastogenically to AV. In this report, we describe experiments addressing this point which indicate that the amplification phenomenon is a result of PWM-induced help enhancing the blastogenic response to A. viscosus.

\section{MATERIALS AND METHODS}

\section{Actinomyces viscosus Ultrasonicate Preparations}

The preparation and characterization of the A. viscosus ultrasonicate preparation has already been reported $(14,15)$. Briefly, an isolate of Actinomyces viscosus (GA), obtained from a naturally occuring gingivitis site was kindly provided by Dr. Salam A. Syed. The cultures were grown under anaerobic conditions as previously described by Loesche, et al. (16). The cells were harvested from batch cultures by centrifugation at $12,000 \mathrm{~g}$ for $30 \mathrm{~min}$. The cell pellets were washed in sterile phosphate-buffered saline (PBS; $0.15 \mathrm{M} \mathrm{NaCl}, 0.05 M \mathrm{PO}_{4}, \mathrm{pH} \mathrm{7.4)}$ and finally resuspended in sterile distilled water. The washed cells were subjected to a total of $\mathbf{4 0}$ min of ultrasonic disruption while in an ice bath (Heat System Ultrasonics, Inc., Model W185D, 85 W), delivered in 5-min intervals with alternating periods of cooling. The cellular debris was removed by centrifugation at $12,000 \mathrm{~g}$ for $30 \mathrm{~min}$. The cell-free supernate (AV) was dialyzed against distilled water at $4^{\circ} \mathrm{C}$ and finally lyophilized.

\section{Mononuclear Cell Isolation and Characterization}

1. Mononuclear cell isolation. Mononuclear leukocytes were isolated from heparinized venous blood drawn from healthy volunteers between the ages of 21 and 40 . The buffy coat layer was prepared from whole blood by centrifugation at $350 \mathrm{~g}$ for $30 \mathrm{~min}$, aspirated, and diluted in sterile PBS, and layered onto Ficoll-Hypaque (17) (Ficoll-Hypaque, Pharmacia Fine Chemicals, Piscataway, N.J.), and centrifuged at $500 \mathrm{~g}$ for $30 \mathrm{~min}$ at $23^{\circ} \mathrm{C}$. The mononuclear leukocytes, which were banded at the interface, were aspirated, washed three times in PBS, and resuspended in RPMI 1640 culture medium (Grand Island Biological Co., Grand Island, N.Y.), supplemented with $30 \mathrm{~m} M$ Hepes buffer, $2 \mathrm{mM}$ glutamine, and gentamycin (50 $\mu \mathrm{g} / \mathrm{ml}$; Schering Corp., Kenilworth, N.J.).

2. Monocyte depletion. Mononuclear cell suspensions were depleted of monocytes by the G-10 Sephadex column method as described by Alonso et al. (18). Passage through such columns resulted in lymphocyte suspensions having less than $4 \%$ monocyte contamination as determined by latex particle uptake (19) and nonspecific esterase staining (20).

3. T- and B-lymphocyte isolation. T cells were prepared from monocytedepleted leukocyte suspensions by rosetting with 2-aminoethylisothiouronium bromide (AET)-treated sheep erythrocytes (sRBCs) (21). Human T cells binding SRBCs were separated from nonrosetted cells by centrifugation through a Ficoll-Hypaque gradient as previously described. The nonrosetted cells banded at the gradient interface while the rosetted $\mathrm{T}$ cell pelleted in the gradient. The $\mathrm{T}$ cells were isolated by lysing the $\mathrm{SRBCs}$ with $0.85 \% \mathrm{NH}_{4} \mathrm{Cl}$. Such $\mathrm{T}$ cell preparations were typically free of B cell and monocyte contamination (>99\% $\mathrm{T}$ cells). The fraction of nonrosetting cells were typically $>90 \% \mathrm{~B}$ cells $(\mathrm{T}$ cell contamina- 
tion was $1-3 \%$ ). B lymphocytes were identified by rosetting with anti-human immunoglobulin-coupled polyacrylamide beads (22; Immunobeads, Bio-Rad laboratories, Richmond, Calif.), and by lack of nonspecific esterase staining (20).

Alternately, $\mathrm{T}$ and $\mathrm{B}$ lymphocytes were purified from monocyte-depleted lymphocyte suspensions by a modification of the method of Chess et al. (23). Briefly, $100 \times 10^{6}$ lymphocytes $\left[20 \times 10^{6} / \mathrm{ml}\right.$ in RPMI 1640 , containing $5 \%$ newborn calf serum and $2.5 \mathrm{mM}$ EDTA (starting buffer)] were incubated for $20 \mathrm{~min}$ at room temperature with $10 \mathrm{ml}$ rabbit anti-human $\mathrm{F}\left(\mathrm{ab}^{\prime}\right)_{2}$-Sepharose $6 \mathrm{~B}$ in a 15-ml plastic column. The nonadherent $T$ lymphocytes were eluted with $15 \mathrm{ml}$ of the starting buffer. Adherent $B$ lymphocytes were then eluted in the following manner; a 5-ml aliquot of human $\gamma$ globulin fraction II (Miles Laboratories, Inc., $10 \mathrm{mg} / \mathrm{ml}$ in RPMI 1640) was passed into the column and incubated for $15 \mathrm{~min}$ at room temperature. Following dispersal of the gel with a pipet, the cells were eluted with an additional $10-\mathrm{ml}$ aliquot of the human $\gamma$ globulin solution. This procedure was performed a second time and the eluants were combined and washed with RPMI 1640 . The resultant B-cell population was at least $90 \%$ B lymphocytes, the balance being monocytes which adsorbed to the Sepharose matrix and were subsequently eluted with the lymphocytes. The T-cell population contained $<1 \%$ B cells as determined by the immunobead reagent.

\section{Lymphocytes Pulsing}

Lymphocytes $\left(2 \times 10^{6} / \mathrm{ml}\right)$ were cultured in RPMI 1640 media for $16 \mathrm{hr}$ in the presence of AV $(10-1000 \mu \mathrm{g} / \mathrm{ml})$ or pokeweed mitogen (PWM; 1/10-1/1000 of stock, Grand Island Biological Co.). Following this culture period, each cell category was washed to remove excess cell stimulants and resuspended in RPMI 1640 media. Various cell suspensions were then subjected to irradiation by a cobalt source at a dose rate of $180 \mathrm{rad} / \mathrm{min}$ for a total of $1500 \mathrm{R}$. Following such treatment, cells were dispensed into microtiter wells, cultured an additional 3 days and processed as described below.

\section{Microculture}

Lymphocyte blastogenesis was assessed in a microtiter plate system as previously described (14). A total of $1 \times 10^{5}$ mononuclear leukocytes were added to each well and cultured in RPMI 1640 medium supplemented with $10 \%$ autologous plasma. Individual cell categories were cultured at 100,000 cells/well to simulate density effects. During the last $6 \mathrm{hr}$ of culture, $2 \mu \mathrm{Ci}\left[\right.$ methyl $\left.{ }^{3} \mathrm{H}\right]$ thymidine (Amersham, TRA $120,5 \mathrm{Ci} / \mathrm{mmol}$ ) was added to each well. All cultures were harvested with a multiple-automated sample harvested (MASH II, Microbiological Associates) onto glass fiher filters. The filters were dried, placed in plastic vials filled with $3 \mathrm{ml}$ scintillation cocktail (OCS, Amersham), and counted in a Packard Model 3320 liquid scintillation spectrometer. The "observed" counts per minute in the individually cultured cell categories represents one-half of the actual value obtained in order to indicate the contribution of each cell category $(50,000$ cells) to the coculture value $(100,000$ cells total). 
TABLE 1

MoNoCyte INFLUENCE ON AV-PWM-ASSOCiated AMPLification ${ }^{a}$

\begin{tabular}{cccc}
\hline & $\begin{array}{c}\text { Monocyte } \\
\text { depleted }\end{array}$ & $\begin{array}{c}\text { Unstimulated } \\
(\text { cpm } \pm \text { SE) }\end{array}$ & $\begin{array}{c}\text { PWM stimulated } \\
\text { (cpm } \pm \text { SE) }\end{array}$ \\
\hline $\mathrm{P}$ & - & $1286 \pm 168$ & $118,124 \pm 5137$ \\
$\mathrm{P}_{\mathrm{av}}$ & - & $1890 \pm 699$ & $187,030 \pm 1413$ \\
$\mathrm{P}$ & + & $1466 \pm 322$ & $57,861 \pm 4184$ \\
$\mathrm{P}_{\mathrm{av}}$ & + & $1454 \pm 352$ & $250,956 \pm 4727$ \\
\hline
\end{tabular}

" Monocyte-depleted or unfractionated lymphocyte suspensions $\left(2 \times 10^{6} / \mathrm{ml}\right)$ were pulsed with AV $(100 \mu \mathrm{g} / \mathrm{ml})\left(\mathrm{P}_{\mathrm{av}}\right)$ or culture media (control) (P) for $16 \mathrm{hr}$. After washing, the cells $(100,000$ per well) were cultured in the presence or absence of PWM (1/100) for an additional $72 \mathrm{hr}$. These results are representative of five such independent experiments.

\section{RESULTS}

Identification of the Role of Actinomyces viscosus and PWM in the

\section{Amplification Phenomenon}

In preliminary experiments (Table 1) the influence of monocytes on the amplification phenomenon was assessed. While amplification was apparent whether or not the monocytes were present, the magnitude of the enhancement was higher when they were removed. This is primarily a function of the blastogenic response to pokeweed mitogen, which is depressed when monocytes are removed. Therefore, monocyte depletion was performed in all subsequent studies to minimize the blastogenic response to PWM, and thus maximize the amplification phenomenon which occurred in the absence of monocytes.

Our previous report (14) indicated that while amplification could be enhanced by adding fresh autologous lymphocytes to $\mathrm{AV}$-precultured cells prior to mitogen stimulation, neither the cell nor the stimulant mediating the phenomenon was apparent. In order to characterize the role of each stimulant, separate autologous monocyte-depleted lymphocyte suspensions were pulsed with either AV (100 $\mu \mathrm{g} / \mathrm{ml})$ or PWM (1/100) for $16 \mathrm{hr}$ followed by washing and coculture for an additional $72 \mathrm{hr}$. As shown in Table 2, coculture of PWM-pulsed cell $\left(\mathrm{P}_{\mathrm{pwm}}\right)$ with AV-pulsed cells $\left(P_{a v}\right)$ resulted in a blastogenic response which was (i) much greater than expected (calculated for this coculture category, and (ii) significantly $(P<0.005)$ greater than the response obtained by the control cocultures $\left(\mathrm{P}+\mathrm{P}_{\mathrm{av}}\right.$; $\left.\mathrm{P}+\mathrm{P}_{\mathrm{pwm}}\right)$. To determine which category of pulsed cell $\left(\mathrm{P}_{\mathrm{av}}\right.$ or $\left.\mathrm{P}_{\mathrm{nwm}}\right)$ was undergoing enhanced blastogenesis, following preculture with either AV or PWM, the cells were irradiated to inhibit proliferation in the coculture yet leave radioresistant regulatory functions intact. Irradiation of the $\mathrm{P}_{\mathrm{av}}$ category greatly reduced the amplified response (expected $\mathrm{cpm}=9924$, observed $\mathrm{cpm}=11,362)$ in the $\mathrm{P}_{\mathrm{av}_{i}}+$ $P_{\text {pwm }}$ coculture. In contrast, irradiation of PWM-pulsed cells had little effect on the coculture amplified response $\left(\mathrm{P}_{\mathrm{av}}+\mathrm{P}_{\mathrm{pwm}}\right.$; expected $\mathrm{cpm}=867$, observed $\mathrm{cpm}$ $=22,780$ ). These results therefore indicate $\mathrm{AV}$-pulsed cells undergo increased proliferation when cocultured with PWM-pulsed cells. 
TABLE 2

Characterization of the Role of AV and PWM in the Amplification Phenomenon"

\begin{tabular}{|c|c|c|c|}
\hline \multirow[b]{2}{*}{ Categories } & \multicolumn{3}{|c|}{$\left[\right.$ methyl $\left.{ }^{3} \mathrm{H}\right]$ Thymidine incorporation $(\mathrm{cpm} \pm \mathrm{SE})$} \\
\hline & Calculated & Observed & Significance $^{t}$ \\
\hline $\mathbf{P}$ & - & $295 \pm 171$ & \\
\hline $\mathbf{P}_{i}$ & - & $66 \pm 25$ & \\
\hline $\mathbf{P}_{\mathrm{pwm}}$ & - & $9,866 \pm 751$ & \\
\hline $\mathbf{P}_{\mathbf{p w m}_{i}}$ & - & $758 \pm 294$ & \\
\hline $\mathbf{P}_{\mathrm{av}}$ & - & $109 \pm 53$ & \\
\hline$P_{\mathrm{av}_{i}}$ & - & $58 \pm 30$ & \\
\hline $\mathbf{P}+\mathbf{P}_{i}$ & 361 & $587 \pm 198$ & \\
\hline $\mathrm{P}+\mathrm{P}_{\mathrm{av}_{i}}$ & 353 & $148 \pm 30$ & \\
\hline$P+P_{a v}$ & 404 & $527 \pm 81$ & \\
\hline $\mathbf{P}+\mathbf{P}_{\mathrm{pwm}}$ & 10,161 & $7,738 \pm 427$ & $P<0.005$ \\
\hline$P_{a v}+P_{p w m}$ & 9,975 & $37,049 \pm 5.747$ & $P<0.005$ \\
\hline $\mathbf{P}_{\mathrm{pwm}}+\mathbf{P}_{i}$ & 9,932 & $7,788 \pm 647$ & $P<0.05$ \\
\hline $\mathbf{P}_{\mathrm{pwm}}+\mathbf{P}_{\mathrm{av}_{i}}$ & 9,924 & $11,362 \pm 1,184$ & $r<0.03$ \\
\hline $\mathbf{P}_{\mathrm{pwm}_{i}}+\mathbf{P}$ & 1,035 & $2,004 \pm 109$ & \\
\hline $\mathbf{P}_{\mathrm{pwm}_{i}}+\mathbf{P}_{\mathrm{av}}$ & 867 & $22,780 \pm 412$ & -0.001 \\
\hline
\end{tabular}

"Monocyte-depleted lymphocytes $\left(2 \times 10^{6} / \mathrm{ml}\right)$ were cultured in the presence of pokeweed mitogen $\left(P_{p w m} ; 1 / 100\right.$ stock $)$, AV $\left(P_{a y} ; 100 \mu \mathrm{g} / \mathrm{ml}\right)$, or culture media alone $(P)$ for $16 \mathrm{hr}$. After washing, the cells were irradiated $(; ; 1500 \mathrm{R})$ as described. The indicated cell categories were cocultured for an additional $72 \mathrm{hr}$. Six hours prior to termination, $2 \mu \mathrm{Ci}\left[\right.$ methyl- $\left.{ }^{3} \mathrm{H}\right]$ thymidine was added to each culture in order to assess DNA synthetic activity. The results are representative of six independent experiments.

"Significant difference between observed values (Student's $t$ test).

\section{Characterization of the Cells Responding to $A V$}

Evidence from the previous experiment indicated that PWM was inducing a helping activity which facilitated the blastogenic response to AV. The ability of the PWM-induced helper to facilitate the AV-induced response over a range of AV concentrations was next assessed. Monocyte-depleted lymphocyte suspensions were pulsed with various concentrations of $\operatorname{AV}(0.1-1000 \mu \mathrm{g} / \mathrm{ml})$ and then cocultured with irradiated PWM-pulsed autologous cells as previously described. As shown in Fig. 1, there is a dose-dependent increase in the lymphocyte response to $\mathrm{AV}$, reaching a maximum at $100 \mu \mathrm{g} / \mathrm{ml}$.

The cell type(s) responding to AV under these conditions was assessed in a similar manner. T- and B-enriched lymphocyte fractions were pulsed with AV $(100 \mu \mathrm{g} / \mathrm{ml})$ for $16 \mathrm{hr}$. Simultaneously, a monocyte-depleted lymphocyte fraction was pulsed with PWM (1/100) to serve as a source of helper activity. After washing and irradiation of the PWM-pulsed cells, the various cell categories were cocultured. As shown in Fig. 2, both B and T subfractions could be shown to respond to AV stimulation.

\section{Characterization of the Cells Providing Helper Activity}

Since PWM was previously shown to be capable of inducing helper activity, it 


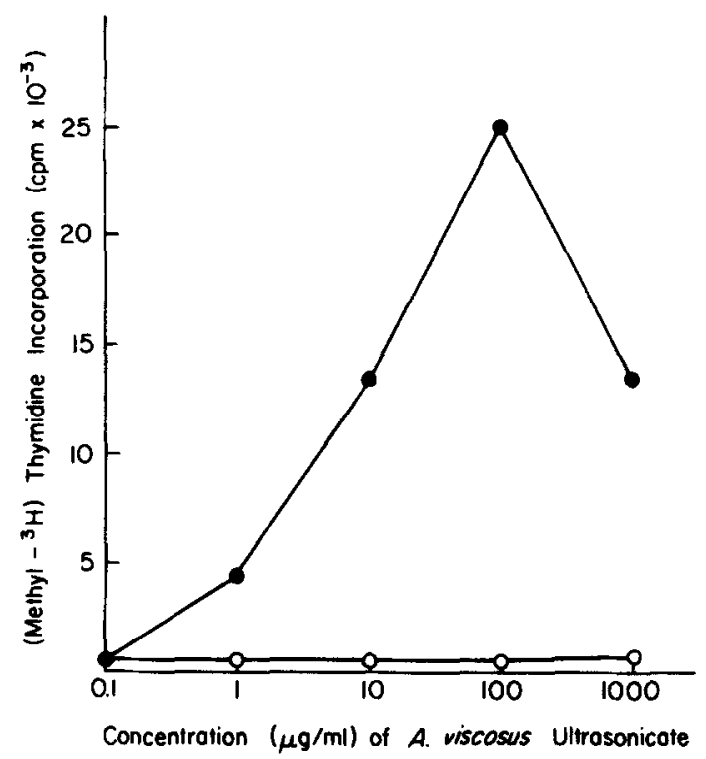

FIG. 1. Dose-dependent response to $A$. viscosus ultrasonicate. Lymphocyte suspensions $(2 \times$ $\left.10^{6} / \mathrm{ml}\right)$ were pulsed with AV $(10-1000 \mu \mathrm{g} / \mathrm{ml})$ for $16 \mathrm{hr}$. After washing, these cells $\left(\mathrm{P}_{\mathrm{av}}\right)$ were cocultured with irradiated, PWM-pulsed $\left(1 / 100, P_{p_{w}}\right)$ lymphocytes and cultured for an additional $72 \mathrm{hr}$. The blastogenic responses of $\left[\mathrm{P}_{\mathrm{av}}+\mathrm{P}_{\mathrm{pwm}}\right](\Theta)$ are compared to that of the control cultures $\left[\mathrm{P}_{\mathrm{av}}+\mathrm{P}_{i}\right](0)$.

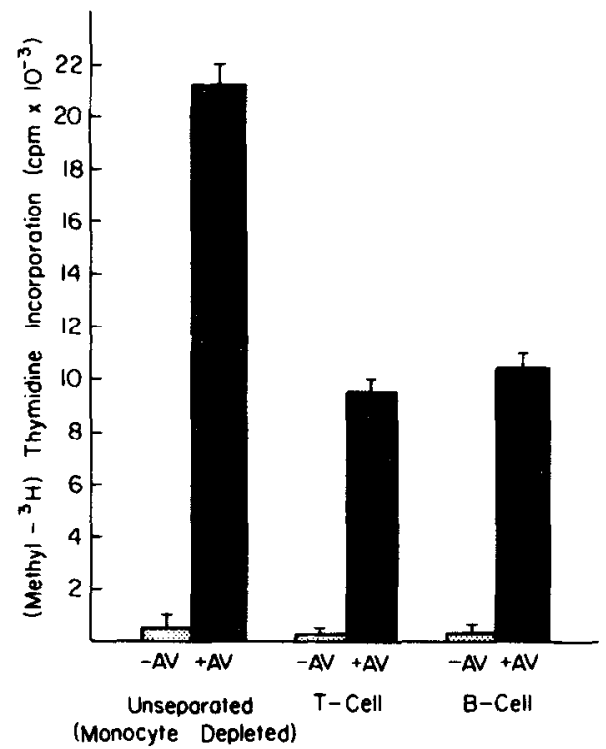

FIG. 2. Lymphocyte subpopulations responding to AV with PWM-induced helper activity. B and T lymphocytes purified by sheep RBC rosetting or unseparated cells were pulsed with AV $(100 \mu \mathrm{g} / \mathrm{ml})$ for $16 \mathrm{hr}$. After washing, they were cocultured with irradiated, PWM-pulsed (1/100 of stock) lymphocytes (unfractionated) and cultured an additional $72 \mathrm{hr}$. 
was of interest to determine if such an effect was dose dependent, i.e., producing help at suboptimal concentrations and possibly suppression at the optimal and/or supraoptional concentrations. Concentrations of PWM between $1 / 1000$ and $1 / 10$ of the stock PWM were used to induce helper activity. As shown in Fig. 3, maximum helper activity occurred at $1 / 1000$ of stock; however, at 1/10 (10 times greater than optimal concentration required for maximal blastogenic response), there is still enhancement.

The nature of the cells responsible for the helper activity was determined by culturing monocyte-depleted, T lymphocyte and B-enriched lymphocytes with PWM (1/100 stock) for $16 \mathrm{hr}$. After washing and irradiation, as previously described, they were cocultured with AV-pulsed monocyte-depleted lymphocytes. The results are shown in Table 3. PWM-pulsed, monocyte-depleted cells (unscparated) facilitated a significant $(P<0.001)$ amplification of the AV blastogenic response (38,888 vs $8963 \mathrm{cpm})$. Similarly, PWM-pulsed T lymphocytes produced an equivalent enhancement (34,576 vs $3778 \mathrm{cpm})$. PWM-pulsed B-enriched cells also produced enhancement of the AV blastogenic response $(95,573$ vs 44,774 cpm). Examination of the non-AV-pulsed controls (e.g., $B_{p_{w m}}+P$ ) revealed that PWM-pulsed cells also stimulated a mitogenic activity in the control cells. The ability to produce such a mitogenic effect was greatest in PWM-pulsed B-enriched cells.

In the previous experiment we showed that PWM-induced helper activity could facilitate the blastogenic responses of both $\mathrm{B}$ and $\mathrm{T}$ lymphocytes. Since the experiment above revealed that both $B$ and $T$ lymphocytes were capable of provid-

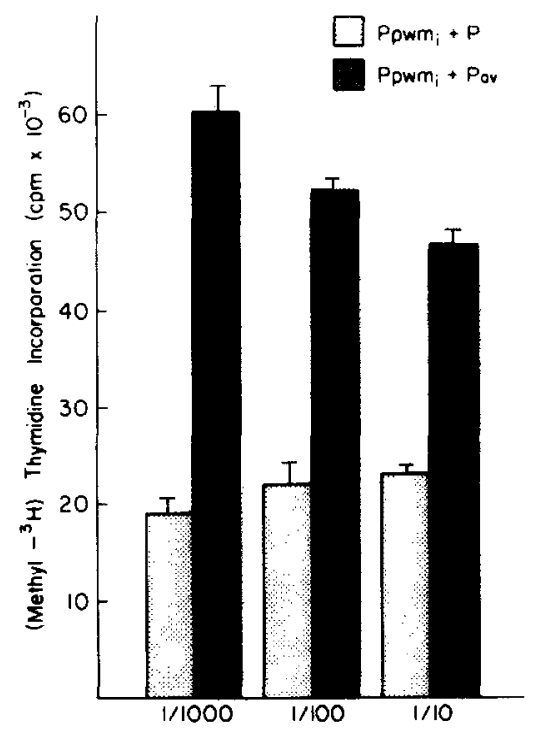

Concentration (Oilution of Slock Solution) of PWM

FIG. 3. Dose-dependent response to PWM: helper induction. Unfractionated lymphocytes suspensions $\left(2 \times 10^{2} / \mathrm{ml}\right)$ were pulsed with PWM (1/10-1/1000 of stock) for $16 \mathrm{hr}$. After washing, they were irradiated $\left(\mathrm{P}_{\mathrm{pw} m}\right)$ and cocultured with $\mathrm{AV}(100 \mu \mathrm{g} / \mathrm{ml})$-pulsed $\left(\mathrm{P}_{\mathrm{av}}\right)$ or control $(\mathrm{P})$ lymphocytes for an additional $72 \mathrm{hr}$. The blastogenic response of $\left[\mathrm{P}_{\mathrm{pwm}_{i}}+\mathbf{P}_{\mathrm{av}}\right]$ is compared to $\left[\mathrm{P}_{\mathrm{pw} \mathrm{m}_{i}}+\mathrm{P}\right]$ at each $\mathbf{P W M}$ concentration. 


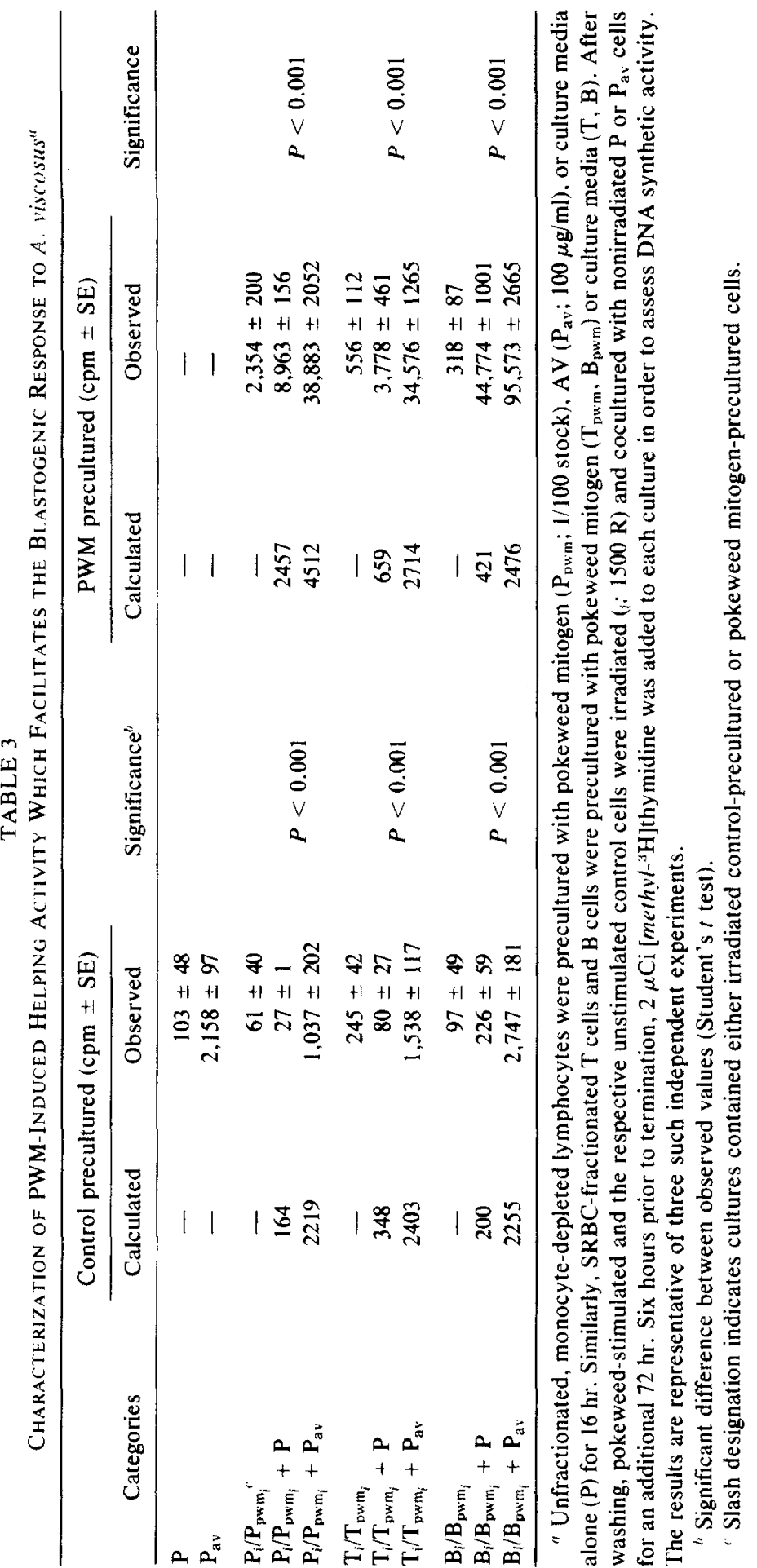


ing help, we examined the ability of PWM-stimulated $T$ and $B$ cells to amplify AV-stimulated T and B cells. As shown in Table 4, while PWM-pulsed T cells provided help to AV-pulsed T cells, PWM-pulsed B cells were not able to facilitate a B-cell response to $A V$. However, both combinations $\left(B_{\mathrm{pwm}_{i}}+\mathrm{T}_{\mathrm{av}}\right)$ and $\left(\mathrm{T}_{\mathrm{pwm}_{i}}+\right.$ $B_{a v}$ ) resulted in an amplified response, suggesting that a $T$ cell is involved in the mediation of B-cell-associated help.

In order to determine whether a T-cell contaminant in the B-cell suspension was responsible for the $\mathrm{B}$-associated help, the number of helper cells required to facilitate the AV response was assessed. In these experiments, graded numbers of irradiated, PWM-pulsed helping cells (unfractionated, and anti-F $\left(a b^{\prime}\right)_{2}$ columnpurified $B$ and T lymphocytes) were added to cultures containing 75,000 AV (100 $\mu \mathrm{g} / \mathrm{ml}$ )-pulsed unfractionated lymphocytes. As shown in Fig. 4, in all cases, as few as 500 monocyte-depleted lymphocytes $\left(1: 150, \mathrm{P}_{\mathrm{pwm}_{i}}: \mathrm{P}_{\mathrm{av}}\right)$ produced significant $(P$ $<0.05)$ enhancement of the AV-induced response. Such enhancement was dose dependent, i.e., with increasing numbers of PWM-pulsed cells there were increased levels of enhancement.

\section{DISCUSSION}

We previously reported (14) that preculture of human lymphocytes with ultrasonicated preparations of Actinomyces viscosus (AV), followed by stimulation of those cells with pokeweed mitogen (PWM) resulted in a synergistic or amplified blastogenic response when compared to the sum of the individual responses to AV and PWM. The nature of the amplification was not clear at that time. In this

TABLE 4

Influence of PWM-Induced Helper Activity on A. viscosus-Pulsed B AND T LYMPHOCYTES

\begin{tabular}{|c|c|c|c|c|}
\hline \multirow[b]{2}{*}{ Categories } & \multicolumn{4}{|c|}{$\left[\right.$ methyl $\left.-{ }^{3} \mathrm{H}\right]$ Thymidine incorporation $(\mathrm{cpm} \pm \mathrm{SE})$} \\
\hline & Control precultured & Signiticance" & PWM precultured & Significance \\
\hline $\begin{array}{l}\mathrm{T}_{i} / \mathrm{T}_{\mathrm{pwm}_{i}}{ }^{c}+\mathrm{T} \\
\mathrm{T}_{i} / \mathrm{T}_{\mathrm{pwm}_{i}}+\mathrm{T}_{\mathrm{av}}\end{array}$ & $\begin{array}{l}110 \pm 62 \\
841 \pm 228\end{array}$ & $P<0.05$ & $\begin{array}{r}2,369 \pm 275 \\
14,742 \pm 514\end{array}$ & $P<0.001$ \\
\hline $\begin{array}{l}\mathrm{T}_{i} / \mathrm{T}_{\mathrm{pwm}_{i}}+\mathbf{B} \\
\mathrm{T}_{i} / \mathrm{T}_{\mathrm{pwm}_{i}}+\mathrm{B}_{\mathrm{av}}\end{array}$ & $\begin{array}{l}572 \pm 183 \\
927 \pm 48\end{array}$ & NS & $\begin{array}{l}19,738 \pm 259 \\
31,408 \pm 842\end{array}$ & $P<0.001$ \\
\hline $\begin{array}{l}\mathbf{B}_{i} / \mathbf{B}_{\mathrm{pwm}_{i}}+\mathbf{B} \\
\mathbf{B}_{i} / \mathbf{B}_{\mathrm{pwm}_{i}}+\mathbf{B}_{\mathrm{av}} \\
\mathbf{B}_{i} / \mathbf{B}_{\mathrm{pwm}_{i}}+\mathrm{T} \\
\mathbf{B}_{i} / \mathbf{B}_{\mathrm{pwm}_{i}}+\mathbf{T}_{\mathrm{av}}\end{array}$ & $\begin{aligned} 282 & \pm 182 \\
740 & \pm 257 \\
50 & \pm 35 \\
1200 & \pm 195\end{aligned}$ & $P<0.005$ & $\begin{aligned} 876 & \pm 217 \\
1,020 & \pm 79 \\
23,870 & \pm 883 \\
49,672 & \pm 2373\end{aligned}$ & $P<0.001$ \\
\hline
\end{tabular}

" SRBC-fractionated T cells $(\mathrm{T})$ or B cells $(\mathrm{B})\left(2 \times 10^{6} / \mathrm{ml}\right)$ were cultured in the presence of pokeweed mitogen $\left(T_{p w m}, B_{p w m} ; 1 / 100\right.$ stock), AV $\left(T_{a v}, B_{a v} ; 100 \mu \mathrm{g} / \mathrm{ml}\right)$, or cultured media alone (T,B) for $16 \mathrm{hr}$. After washing, the PWM-stimulated and the respective control cells were irradiated $\left({ }_{i} ; 1500 \mathrm{R}\right)$ as described. The indicated cell categories were cocultured for an additional $72 \mathrm{hr}$. Six hours prior to termination, $2 \mu \mathrm{Ci}$ [methyl ${ }^{3} \mathrm{H}$ ] thymidine was added to each culture in order to assess DNA synthetic activity. The results are representative of two independent experiments.

"Significant difference between control and test categories (Student's $t$ test).

"Slash designation indicates cultures contained either irradiated control-precultured or PWMprecultured cells. 


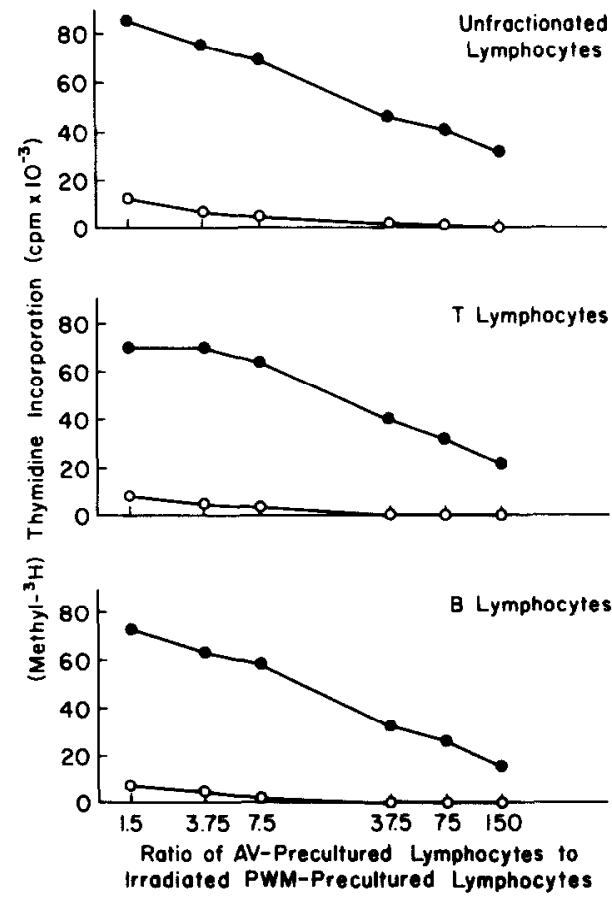

FIG. 4. Helper cell titration. To a constant number $(75,000)$ of unfractionated AV-pulsed ( $100 \mu \mathrm{g} / \mathrm{ml})$ (O) or media control $(O)$ lymphocytes was added increasing numbers of irradiated PWM-pulsed (1/100) unfractionated, or anti- $\mathrm{F}\left(\mathrm{ab}^{\prime}\right)_{2}$ column purified $\mathrm{T}$ or $\mathrm{B}$ lymphocytes. The blastogenic response of the coculture cells was assessed after an additional $72 \mathrm{hr}$ in culture.

report, we described further studies which indicate that PWM pulsing of lymphocytes induces a helping activity which facilitates the blastogenic response to AV. The cells responding to AV were shown to be of the B and T-lymphocyte subclasses. Studies using murine culture systems also describe the polyclonal activation of $B$ and $T$ cells by AV preparations $(10,11)$.

Distinct helping activities were shown to be manifested by the two lymphocyte cell types. A T-cell-mediated helping activity, able to be activated by PWM, was shown to facilitate the AV response. In similar studies (13) a mitogen-activated T-helping activity was also shown to facilitate the blastogenic response of human lymphocytes to lipopolysaccharide (LPS). The B-cell-enriched population also appeared to be capable of providing help for the response to AV preparations. At a ratio of one B-enriched cell per $150 \mathrm{AV}$-precultured cells, a significant level of help was measured (Fig. 4). However, since the level of T-cell contamination in the B-cell-enriched suspension ranged $1-3 \%$, there remains the possibility that as many as $15 \mathrm{~T}$ cells could be providing help to the AV-precultured lymphocytes. The potential of $\mathrm{T}$-cell involvement must be considered in the following discussion of a possible B-cell role in the help effect. PWM activation of the B-enriched population produced two phenomena. First, enhancement of the AV response to levels greater than attained by PWM-stimulated helper $\mathrm{T}$ cells was measured. This enhancement was in addition to a second nonspecific enhancement of proliferative activity which was independent of the response to AV. The ability to exert such 
activity in other lymphocyte fractions was much less and appeared to be related to the B-cell content of the PWM-pulsed fraction, i.e., B > monocyte-depleted, unseparated cells $>\mathrm{T}$.

The nature of B-cell helper activity is still uncertain. In the experiments shown in Table 4, $\left[\mathrm{B}_{\mathrm{pwm}_{i}}+\mathrm{B}_{\mathrm{av}}\right]$ did not result in enhancement, while $\left[\mathrm{T}_{\mathrm{pwm}_{i}}+\mathrm{T}_{\mathrm{av}} ; \mathrm{T}_{\mathrm{pwm}}\right.$ $+B_{a v}$; and $\left.B_{p_{w m}}+T_{a v}\right]$ did. This suggests that the $B$ helping activity either does not act on AV-pulsed $B$ cells, or that its generation requires the presence of a $T$ cell either in the helping cell fraction or resident in the AV-pulsed cell fraction.

Helping cell activity has been shown to facilitate other poorly mitogenic substances of bacterial origin $(24,25)$. The requirement for a radioresistant $\mathrm{T}$ cell for B lymphocyte response to mitogens has been described by MacDermott et al. (26). Miller et al. (27) have reported that long-term culture was required to activate a $T$ helper cell which could facilitate the blastogenic response of human peripheral blood lymphocytes to purified LPS. The presence of helper cell populations have been described by DuBois et al. (28), whereby irradiated autologous or allogenic cells were capable of reconstituting in vitro proliferative responses, even if the reconstituting cells themselves were unresponsive to the stimulant.

The mechanism by which the B cell (as well as $\mathrm{T}$ cell) facilitates the blastogenic response to AV remains to be elucidated. However, several modes of action have been described by others. Lymphokine synthesis by B cells, independent of blastogenesis, has been described (8). One such B lymphokine is reported to possess mitogenic activity. Another method of amplification may result from an increase in the rate of spontaneous proliferation, or background, which has been suggested as an important factor in the response of lymphocytes to certain stimulants (29). The ability of B-cell produced lymphokines to enhance the sensitivity of lymphocytes to stimulation may be an important factor in perpetuating inflammatory lesions associated with specific microorganisms. The relationship between the nonspecific mitogenesis and amplification of the AV response is not clear at present, and in fact, may be distinct phenomena. The existence of regulatory $B$ cells which influence immune responses to substances such as LPS (30) and picryl chloride (31) have also been documented. While these cells have been characterized as supressor cells in those studies, presence of helper B cells, in our cultures, cannot be discounted.

The generation of mitogenic substances during inflammation by neutrophils (32), monocyte and macrophages (33), or the inherent mitogenic factors in bacterial and fungal products (34), may provide sufficient triggering of nonspecific helping $\mathrm{T}$ - and B-cell activity to facilitate the immune response to normally "silent" mitogenic substances as characterized by $A$. viscosus. Under nondisease situations, T-cell regulation, especially help, may predominate because of the low levels of circulating $B$ lymphocytes relative to $T$ cells. However, in inflammatory lesions, characterized by high numbers of $\mathrm{B}$ cells and plasma cells (35), B-cell regulation may play a significant role in facilitating immune responses to certain bacterial products.

Work in progress in our laboratory is evaluating the nature of T- and B-cell help of immune responses to bacterial substances. Especially of interest is the nature of the nonspecific mitogenicity associated with the mitogen-pulsed $B$ cell and its relationship to B-cell help. 


\section{ACKNOWLEDGMENTS}

We thank Dr. Stanley A. Schwartz, Department of Pediatrics, University of Michigan, for his invaluable suggestions on this manuscript, and Ms. Holly Anderson-Davis of the Phoenix Memorial Laboratory for her help in the Cobalt-51 irradiation studies. This study was supported by Public Health Service Grant DEO2731 from the National Institute of Dental Research.

\section{REFERENCES}

1. Williams, B. L., Pantalone, R. M., and Sherris, J. C., J. Periodontal Res. 11, 1, 1976.

2. Slack, J. M., and Gerencser, M. A., "Actinomyces, Filamentous Bacteria. Biology and Pathogenicity." Burgess, Minneapolis, Minn., 1975.

3. Brown, J. R., Hum. Pathol. 4, 319, 1973.

4. Davenport, A. A., Carter, G. R., and Schirmer, R. G., Vet. Med. Small Anim. Clin. 69, 1442. 1974.

5. Irving, J. T., Socransky, S. S., and Heeley, J. D., J. Periodontal Res. 9, 73, 1974.

6. Taichman, N. S., and McArthur, W. P., Arch. Oral Biol. 21, 257, 1976.

7. Baker, J. J., Chan, S. P., Socransky, S. S., Oppenheim, J. J., and Mergenhagen, S. F., Infect Immun. 13, 1363, 1976.

8. Mackler, B. F., Altman, L. C., Wahl, S., Rosenstreich, D. L., Oppenheim, J. J., and Mergenhagen. S. E., Infect. Immun. 10, 884, 1974.

9. Patters, M. R., Sedransk, N., and Genco, R. J., J. Periodontal Res. 14, 269, 1979.

10. Engel, D., Claquett, J., Page, R., and Williams, B., J. Immunol. 118, 1466, 1977.

11. Burckhardt, J. J., Guggenheim, B., and Hetti, A., J. Immunol. 118, 1460, 1977.

12. Horton, J. E., Oppenheim, J. J., Chan, S. P., and Baker, J. J., Cell. Immunol. 21, 153, 1976.

13. Lopatin, D. E., Mangan, D. F., Horner, I. S., and Peebles, F. L., Infect. Immun. 29, 512, 1980.

14. Lopatin, D. E., Peebles, F. L., and Horner, I. S., Clin. Immunol. Immunopathol. 16, 75, 1980.

15. Lopatin, D. E., Peebles, F. L., Woods, R. W., and Syed, S. A., Arch. Oral Biol. 25, 23, 1980.

16. Loesche, W. J., Hackett, R. N., and Syed, S. A., Arch. Oral Biol. 17, 1311. 1972.

17. Bøyum, A., Scand. J. Clin. Lab. Invest. (Suppl.) 21, 1, 1968.

18. Alonso, C. M., Bernabe, R. R., Moreno, E., and DeEspada, F. D., J. Immunol. Methods 22, 361 , 1978 .

19. Oppenheim, J. J., Leventhal, B. G., and Hersh, E. M., J. Immunol. 101, 262, 1968.

20. Koski, I. R., Poplack, D. G., and Bledse, R. M., In "In Vitro Methods in Cell-Mediated and Tumor Immunity" (B. R. Bloom, and J. R. David, Eds.), pp. 359-362, Academic Press, New York, 1976.

21. Kaplan, M. E., and Clark, C., J. Immunol. Methods 5, 131, 1974.

22. Chao, W., and Yokoyama, M. M., Clin. Chem. Acta 78, 79, 1977.

23. Chess, L., MacDermott, R. P., and Schlossman, S. F., J. Immunol. 113, 1113, 1974.

24. Yokoyama, K., and Oswaw, T., Immunology 38, 789, 1979.

25. Forbes, J. T., Nakao, Y., and Smith, R. T., J. Immunol. 114, 1004, 1975.

26. MacDermott, R. P., Nash, G. S., Bertovich, M. J., Merkel, N. S., and Weinrieb, I. J., Cell. Immunol. 38, 198, 1978.

27. Miller, R. A., Gartner, S., and Kaplan, H. S., J. Immunol. 114, 742, 1978.

28. DuBois, M. G. J., Ejjlander, A. B., Meinesz, A., and Schellenkens, P. T. A., Cell. Immunol. 41. 338. 1978.

29. Bretscher, P. A., Eur. J. Immunol. 8, 534, 1978.

30. Koenig, S., and Hoffman. M. K., Proc. Nat. Acad. Sci. USA 79, 4608, 1979.

31. Zembala, M., Asherson. G. L., Noworolski, G. L., and Mayhew, B., Cell. Immunol. 25, 266, 1976.

32. Yoshinaga, M.. Nakamura, S., and Hayashi, H., J. Immunol. 115, 533, 1975.

33. Farrar, J. J., Simon, P. L., Koopman, W. J., and Fuller-Bonur, J., J. Immunol. 121, 1353, 1978.

34. Banck. G., and Forsgren, A., Scand. J. Immunol. 8, 347, 1978.

35. Mackler, B. F., Frostad, K. B., Robertson, P. B., and Levy, B. M., J. Periodıntal Res. 12, 37. 1977. 